\title{
Bilişim Teknolojileri - İş Uyumlamasi İçin Gerekli Örgütsel Faktörler (Organizational Factors Required For Information Technology-Business Alignment)
}

\section{Said ALTINIŞIK iD a}

a Düzce Üniversitesi, İşletme Fakültesi, Yönetim Bilişim Sistemleri Bölümü, Düzce, Türkiye. saidaltinisik@duzce.edu.tr

\begin{tabular}{l} 
MAKALE BİLGİṠ \\
\hline Anahtar Kelimeler: \\
BT-İş Stratejileri Uyumlaması \\
Stratejik BT Uyumlaması \\
İş Stratejileri
\end{tabular}

Gönderilme Tarihi 6 Temmuz 2021

Revizyon Tarihi 1 Aralık 2021 Kabul Tarihi 12 Aralık 202

Makale Kategorisi:

Araştırma Makalesi

\section{ÖZET}

Amaç - Bu çalışma firmalarda bilişim teknolojileri (BT) ve iş stratejileri uyumlaması için gerekli olan örgütsel faktörleri saptamayı amaçlamaktadır.

Yöntem - Bir anket uygulaması aracılığıyla literatürden elde edilen on faktörün BT-İş uyumuna etkisi incelenmektedir. Ankara Ticaret Odası'na kayıtlı orta ve büyük ölçekli firmalarda görevli 166 üst düzey yöneticiden söz konusu on faktörün etkisi hakkındaki görüşleri alınmış, ayrıca firmaların bu faktörlerdeki algılanan başarısı ile firmaların bilişim teknolojileri ve iş stratejileri uyum puanları korelasyon analizine tabi tutulup bu faktörlerin etkisi test edilmiştir.

Bulgular - Analizler sonucunda test edilen on faktörün toplamda iş stratejileri ve bilişim uyumu arasında yüksek poziti ilişki olduğu (r=.723) saptanmıştır. Özellikle şu dört faktörün yüksek pozitif ilişkisi olduğu kaydedilmiştir: üst yönetimin BT'ye destek olmaları/arka çıkmaları, bilişim sisteminin stratejik kullanımında kararlılık, bilişim ve iş planlamalarının bütünleşmesi, BT yöneticilerinin iş dünyasından haberdar olmaları.

Tartışma - Bulgular bize BT-İş uyumunun elde edilmesi için teknik yaklaşımlardan ziyade ilişkisel ve yönetimsel boyutun önemli olduğu ortaya çıkmıştır. Firma yönetimine bakan boyutuyla özellikle BT yönetiminin iş süreçlerine ve planlamalara dahil edilmesi gerektiği ve üst yönetimin bilişim sistemleri projeleri için sıkı destek vermeleri gerektiği vurgulanmıştır.

ARTICLE INFO
Keywords:
IT and Business Strategies
Alignment
Strategic IT Alignment
Business Strategies

Received 6 July 2021

Revised 1 December 2021

Accepted 12 December 2021

Article Classification:

Research Article

\section{ABSTRACT}

Purpose - This study aims to examine the antecedent factors of IT (Information Technology) and business strategies alignment.

Design/Method/Approach - By using the survey method the effect of ten factors derived from the relevant literature on the IT-Business alignment. We acquired the perspectives of 71 executives from middle to large sized firms registered to Ankara Chamber of Commerce (ATO) on those factors' effect on alignment and we also checked the effectiveness of these factors with actual measures by correlating their perceived success in these factors with their IT alignment level.

Findings - We found out that our ten factors collectively have a high correlation ( $r=.723)$ with the Business-IT alignment score. Three factors appeared to be strongly effective in attaining IT-business alignment: executive support for IT, commitment to strategic use of IT, business-IT planning integration, IT staff understands business.

Discussion - Findings revealed that relational and managerial dimensions are more important than technical approaches to achieve IT-Business alignment. It is emphasized that especially IT management should be included in business processes and planning and senior management should provide firm support for information systems projects. 


\section{Giriş}

Teknolojinin ticari etkileşimin önemli bir bileşeni olduğu günümüz firmalarında bilişim teknolojilerine (BT) büyük miktarlarda yatırımlar yapılmasına rağmen bu yatırımlardan arzu edilen neticeler alınamamakta (Teo ve King, 1997), birçok bilişim sistemi uygulama ${ }^{1}$ projeleri başarısız olmakta veya beklenenin altında verimle kullanılmaktadır (Pressman, 2009). Bu yaygın problem için öne sürülen sebepler arasında önde gelen bir etkenin BT ile firmanın stratejik yönelişleri arasındaki uyumsuzluk olduğu çoklukla dile getirilmiştir (Henderson ve Venkatraman, 1999; Yayla , Hu, 2009). BT-İş uyumlaması (IT Alignment) Reich ve Benbasat (1996) tarafından iş stratejileri içerisindeki misyon, hedefler ve planların BT stratejileri tarafından ne kadar paylaşıldığı ve desteklendiğini belirten bir değer olarak tanımlanmıştır.

Bilişim teknolojilerinin stratejik önemi arttıkça ve firma faaliyetlerindeki operasyonel rolü giderek daha belirgin hale geldikçe firmalar için bu teknolojileri kendi örgütsel yapılarına ve iş modellerine entegre etmek, bu yolla onlardan maksimum fayda elde etmek daha bir önem kazanmıştır. BT -iş uyumunun ampirik olarak kanıtlanmış faydaları arasında bilişim yatırımlarının geri dönüşümünü arttırdığı (Chan, Huff, Barclay, Copeland, 1997), örgütsel kaynakların daha verimli kullanılmasına yol açtığı ve bunun neticesinde firmaya rekabet avantajı sağladığı (Henderson ve Venkatraman, 1999), ve firmanın örgütsel hedeflerini daha efektif takip etmesine olanak verdiği (Yayla ve $\mathrm{Hu}, 2009$ ) zikredilebilir. Bu faydalarından ötürü BT-İş uyumunun sağlanması yöneticiler için, özellikle BT yöneticileri için önde gelen kaygılar arasında olduğu ampirik çalışmalarla da ifade edilmiştir (Luftman, Papp, Brier, 1999).

BT-İş uyumlamasının kayda değer finansal ve performans getirileri olduğu üzerinde ittifak olmasına rağmen bu uyumun nasıl sağlanacağı üzerinde genelgeçer bir uzlaşma bulunmamaktadır. Bir kısım araştırmalar bu uyuşumun sağlanmasını evrimsel bir süreç olarak tanımlamalarına karşılık, literatürdeki çalışmaların önemli bir kısmı bu uyumu adımlardan oluşan bir süreç olarak değil, olumsallık (contingency) paradigması çatısı altında belli koşulların bulunması durumunda elde edilebilecek bir sonuç olarak resmetmişlerdir (Weill ve Olson, 1989). Bu çalışmalar BT-İş uyumu için gerekli öncül faktörleri incelemiş, bu faktörleri bu uyumun sağlanması yolunda birer ön adım olarak öne sürmüşlerdir.

BT Uyumunun öncül faktörleri üzerindeki çalışmalar bulguları aşısından çalışıldığı ülkeye, sektöre göre farklılıklar göstermiştir. Bilişim sistemlerinin doğası gereği bu beklenebilir bir durumdur. Çünkü bilişim sistemi yalnızca teknolojiyi değil insan ve örgüt faktörlerini de kapsayan bir kavramdır, dolayısıyla kültürel kodlar bir bilişim teknolojisinin uygulanma sürecinde belirleyici rol oynamaktadır. Zaten teknolojiyi kullanan ve ondan beklenen faydaları tahakkuk ettirecek olan en nihayetinde yine insan faktörüdir. Dolayısıyla BT uyumu ve ona yol açan faktörler her sosyo-kültürel bağlam için ayrıca incelenmesi gerekmektedir. Türkiye bağlamında ise bu uyumun öncül faktörlerini inceleyen akademik çalışmalara rastlanmamıştır. Dolayısıyla bu çalışma ile literatürdeki bu eksiklik giderilmeye çalışılmış, Türkiye bağlamında BT uyumu ve onun örgütsel öncülleri incelenmeye çalışılmıştır.

\section{Kavramsal Çerçeve}

BT ve iş stratejileri uyumlaması firmalar için nihayeti olmayan ve çok boyutlu dinamik göstergelere dayanan bir hedef olarak ifade edilmiştir (Chan ve Reich, 2007). Bilgi teknolojilerinin şirketin strateji ve faaliyetleri ile entegre olmasının gereği izahtan varestedir. Bunu basit bir analojiyle, insanın sinir sistemi ile açılamak mümkündür. İnsan hem bebeklik dönemlerinde hem de yetişkin hayatında uğraşı, sanatı ve hobileri beynin ilgili kısımlarının ve ilgili kas sistemindeki motor nöronların gelişimlerini etkileyecektir. Bu da kişinin ilgili faaliyetteki becerilerini olumlu yönde etkileyecektir. Aynı şekilde firmanın stratejik yönelimleri, ilgili faaliyetlerin gerçekleştirilmesini mümkün kılan bilgi ve haberleşme teknolojilerini hem alt yapı hem de

\footnotetext{
1 'Uyumlama' sözcüğü kavramın İngilizce dilinde türetildiği şekliyle 'alignment' sözcügüne karşılık olarak seçilmiştir. 'Uyum' veya 'uyuşma' kelimelerine karşllık 'uyumlama' kelimesinin tercih edilme nedeni önceki kelimelerin daha ziyade eşyanın sabit niteliğine atıfta bulunurken, uyumlama sözcügünün kavramın yönetim tarafından sürekli bir uğraşı neticesi elde edilebilir, dinamik niteliğine işaret etmesidir. Nitekim 'alignment' kelimesinin tam karşılı̆̆ı aslında hizalamak fiilidir, dolayısıyla kelime dinamik bir sürece işaret etmektedir. İlgili kavramın Türkçe'deki karşılığı üzerinde bir ittifaka rastlanmadığı için bu açıklamaya ihtiyaç duyulmuştur. Metin içerisinde 'uyum' kelimesi de cümlenin biçimi gereği kullanılsa da asıl kasdedilen uyumlama kavramı olacaktır. Ayrıca ana metni yalın ve akıcı tutmak amacıyla 'BT-İşs stratejileri uyumlaması' mefhumu için çoklukla kısa haliyle 'BT uyumu' tabiri kullanılmaktadır.
} 
doğrudan gerçekleyici olarak gerektirecek ve ilgili teknolojilerin bulunmaları firmaya sürdürülebilir rekabet avantajı sağlayacaktır.

BT-İş uyumu çok boyutlu ve stratejik uyum, yapısal uyum, sosyal ve kültürel uyum gibi birçok vecheleri olan bir nitelik olarak ifade edilmiştir, (Chan ve Reich, 2007). Stratejik uyum diğer adıyla teorik uyum, BT ve iş planlamalarının entegrasyonuna işaret ederken; yapısal uyum organizasyon yapısında BT ve İş yöneticilerinin konumlamalarıyla ilgilidir. Sosyal ve kültürel uyum ise daha ilişkisel ve davranışsal boyutlara, iş ve BT uzmanları arasındaki etkileşimlere temas etmektedir. Bu çalışmada kuramsal yaklaşım olarak BT-İş uyumu tüm boyutlarıyla ele alınmıştır. Örneğin 'iş ve BT planlamalarının eş güdümlü yapılması' stratejik uyuma işaret ederken, 'BT ve iş yönetimi arasındaki iletişim' daha çok kültürel ve sosyal uyuma temas etmektedir.

Literatür bölümünün kalan kısmında çalışmanın üzerine bina edildiği, özellikle BT-Isş uyumunun öncül faktörlerini derlediğimiz akademik çalışmalara yer verilmektedir. Alıntı yapılan makalelerden ilk dördü nitel çalışmalar olup yöneticilerle mülakat tekniği ile elde edilmiş faktörler iken sonrakiler ise bu faktörlerin nicel olarak sorulup puan verilmesi ile elde edilen çalışmalardır. Dolayısıyla ilk grup keşif odaklı iken ikinci grup daha ziyade açıklayıcı ve doğrulayıcı olarak nitelendirilebilir.

Lederer ve Mendelow (1989) tarafından yapılan bir çalışmada 20 üst düzey BT yöneticilerine BT ile iş planlarını nasıl koordine ettikleri sorulmuştur. Onlara göre bu koordinasyon BT'nin firma hedef ve amaçlarına ne kadar destek olduğunun bir göstergesiydi. Röportajlar analiz edildiğinde dört faktörün bu koordinasyonu zorlaştırdığı sonucuna ulaşıldı: iş misyonunun, hedef ve önceliklerin belirsiz ve kararsız olması, iş ve bilişim yöneticileri arasında iletişim eksikliği, BT yönetiminin iş planlama sürecinde müdahil olmamaları, BT'yi kullanan yöneticilerin bilgi eksiklikleri ve gerçekçi olmayan istekleri.

Luftman ve diğ.(1999) tarafından farklı endüstrilerden 1051 yöneticiden BT uyumunu kolaylaştıran ve zorlaştıran faktörleri sıralamaları istendi. Verilen cevaplar sentezlendiğinde şu faktörler elde edildi: (1) Üst yönetimin BT ye destek çıkması, (2) BT yönetiminin strateji geliştirme sürecine katılımları, (3) BT yönetiminin iş dünyasından haberdar olmaları, (4) İş-bilişim ortak çalışmaları, (5) Öncelik verilmiş BT projeleri, (6) BT yönetiminin liderlik kabiliyeti.

Reich ve Benbasat (2000) Kanada' da üç büyük sigorta şirketinin on farklı iş ünitelerinden kırk beş yönetici ile yaptığı mülakatlarla hangi faktörlerin BT uyumunun sosyal boyutuna katkıda bulunduğunu araştırdı. Kısa dönem uyum için gerekli faktörler şu şekilde tespit edildi: (1) BT ve iş yöneticileri arasında ortak alan bilgisi, (2) BT projeleri uygulama başarısı, (3) BT ve iş yönetimi arasında iletişim, (4) BT ve iş planlamalarının bütünleşmesi.

Rathnam ve diğ. (2004) bir Amerikan finans şirketinden hem BT hem iş tarafından on yöneticiye yönelttikleri neden iş ve BT stratejileri arasında bir ayrılık olduğu sorusuna aldıkları cevapları analiz ettiklerinde genel hatlarıyla şu faktörlere ulaştılar: iş stratejilerinin belirsiz olması, iş bölümleri arası uyumsuzluk, BT yönetiminin iş süreçlerine katılmaması, BT ve iş arasında ortak terminolojinin olmaması, ve bu uyumun öneminin farkında olmamak.

Bu nitel çalışmalardan elde edilen bulgular bize BT uyumu için teknik yaklaşımlardan ziyade yönetim odaklı bir yaklaşımın takip edilmesi gerektiğini ve özellikle iki birim arası ilişkisel etkenlerin ve ortak dil kullanımının bu uyumu elde etmede önemli olduğunu ifade etmektedir.

Burada ele aldığımız ikinci grup çalışmalar ise nitel araştırmalardan elde edilen faktörlerin anket yöntemi ile oylanması sonucu elde edilen verilerdir. Teo ve Ang'ın (1999) Singapur' da 136 yöneticiden uyum için gerekli faktörleri oylamalarını istedikleri çalışmalarında elde ettikleri veriler Tablo 2.1'de verilmektedir. Burada yalnız ilk on faktör ortalama puanlarıyla birlikte verilmektedir. 
Tablo 1 BT Uyumuna Yol Açan Faktörler *

1. Üst yönetimin BT'nin stratejik kullanımına kararlı olması

2. BT yönetiminin iş dünyası hakkında bilgi sahibi olmaları

3. Üst yönetimin BT bölümüne güven duymaları

4. BT bölümünün kullanıcı bölümlere etkin ve güvenilir hizmet vermesi

5. BT bölümünün kullanıcı bölümlerle sıkı iletişim halinde olması

6. BT personelinin BT'ndeki gelişmeleri takip etmeleri

7. İş ve BT yönetiminin uygulama önceliklerini belirlemede birlikte çalışmaları

8. İş hedefleri ve amaçlarının BT yönetimince de biliniyor olması

9. BT bölümünün kullanıcı ihtiyaçlarına cevap veriyor olması

*Teo ve Ang (1999)

Aggarwal(2010)'ın çalışmasında Hindistan Petrol sektöründen 367 yöneticiye uygulanan ankette onlardan belli faktörlerin BT uyumunu kolaylaştırdığı $(+2)$ yada zorlaştırdığı $(-2)$ noktasında kanaatleri alındı. Uyumu kolaylaştırıcı faktörler Tablo 2 deki gibi tespit edildi.

Tablo 2 BT Uyumuna Yol Açan Faktörler *

1. Güçlü üst yönetim taahhüdü

2. Firmanın güçlü finansal durumu

3. Üst düzey yönetimin BT bölümüne destek çıkmaları

4. Firmada geniş bilgisayar olanakları

5. BT bölümünün strateji geliştirme sürecine katılmaları

\footnotetext{
*Aggarwal(2010)
}

Buraya kadar ele aldığımız çalışmalar BT uyumunun öncül faktörlerini konunun uzmanları olan yöneticilerden anket ya da görüşme tekniğiyle elde ettikleri hem keşif odaklı hem de açıklayıcı çalışmalardı. Diğer bir sınıf çalışmalar ise bu faktörleri uzman görüşü ile değil reel BT uyum ölçümleri ile faktör puanlarının korelasyonu sonucu yapılan 'doğrulayıcı' çalışmalardır. Bu araştırmalardan Türkiye'de ölçümü yapılan bir çalışmada BT uyumuna İş-BT ortak alan bilgisi, başarılı bir BT geçmişi ve iletişim yönetiminin uyuma tam katkıda bulundukları; BT kararlarının merkezileşmesi ve BT aktivitelerinin formalizasyonun ise kısmi katkıda bulunduğu gösterilmiştir (Yayla ve Hu, 2009). Bu kapsamdaki diğer çalışmalar detaylı olarak zikredilmeyip, özellikle bu çalışmaya kaynak olan araştırmalar Tablo 3'te liste halinde verilmiştir.

Tablo 3 Çalışmada İncelenen Örgütsel Faktörler ve Alındıkları Kaynaklar

\begin{tabular}{|c|c|}
\hline Örgütsel Faktörler & Alındığ1 Kaynaklar \\
\hline BS'nin etkin ve işlevsel olması & (Aggarwal, 2010), (Teo ve Ang, 1999), (Teo ve King, 1997) \\
\hline $\begin{array}{l}\text { Üst yönetimin BT bölümüne } \\
\text { destek olmaları }\end{array}$ & (Aggarwal, 2010), (Chan, 2002), (Teo ve Ang, 1999), (Luftman ve diğ., 1999) \\
\hline $\begin{array}{l}\text { Güzel tanımlanmış iş stratejileri, } \\
\text { misvon ve hedefler }\end{array}$ & (Rathnam ve diğ., 2004), (Lederer ve Mendelow, 1989) \\
\hline $\begin{array}{l}\text { BT'nin stratejik kullanımına } \\
\text { kararlılık }\end{array}$ & (Aggarwal, 2010), (Teo ve Ang, 1999) \\
\hline
\end{tabular}


Üst yönetimin BT dünyasından haberdar olmaları

BT yönetiminin iş dünyasından haberdar olmaları

BT ve iş planlamalarının bütünlesmesi

BT ve iş yönetimi arasında iletișim

BT yönetiminin strateji gelistirme sürecine katılımları

Geçmiş BT başarıları
(Reich ve Benbasat, 2000), (Teo ve Ang, 1999)

(Reich ve Benbasat, 2000), (Teo ve Ang, 1999), (Luftman ve diğ., 1999)

(Aggarwal, 2010), (Chan, 2002), (Reich ve Benbasat, 2000), (Teo ve Ang, 1999)

(Chan, 2002), (Reich ve Benbasat, 2000), (Teo ve Ang, 1999), (Luftman ve diğ., 1999)

(Aggarwal, 2010), (Luftman ve diğ., 1999), (Lederer ve Mendelow, 1989)

(Reich ve Benbasat, 2000), (Luftman ve diğ., 1999)

Tablo 2.3 te bu çalışmada kullanılan faktörlerin hangi çalışmalardan alındığı temel hatlarıyla gösterilmektedir. Bazı faktörler aynı kavrama işaret etmesine rağmen çalışmalarda farklı ifadelerle belirtilmişlerdi, bu faktörler bizim çalışmamızda tek bir kavram olarak ifade edilmiştir. Çalışmamızda incelenen faktörlerin nihai listesi oluşturulurken kural olarak en az iki çalışmada etkin faktör olarak saptanmış olması esas alınmıştır.

\section{Yöntem}

\subsection{Araştırma Modeli}

Bu çalışmada literatürden elde edilen on örgütsel faktörün bilişim teknolojileri ve iş stratejileri uyumlamasına etkisi araştırılmaktadır. Çalışma kapsamında BT-Işs uyumuna yol açan faktörlerin etkinliği iki yolla ölçülmüştür. Öncelikle ankete katılan yöneticilere ilgili faktörün uyum üzerindeki etkinliği beş puanlı Likert ölçeği ile sorulmuş, ikinci olarak da firmanın faktördeki algılanan başarısı ile firmanın BT-İş uyumlama puanı korelasyon analizine tabi tutularak faktörün uyum üzerindeki etkisi ampirik olarak ölçümlenmiştir. Sonra bu iki yöntemin bulguları karşılaştırılarak yorumlanmıştır. Ayrıca ölçeklerin sağladığı bilgiler kapsamında Türkiye'de BT'nin hangi stratejiler için yoğunlukla kullanıldığı, endüstrilere göre BT uyum skorları analizlerine yer verilmiştir.

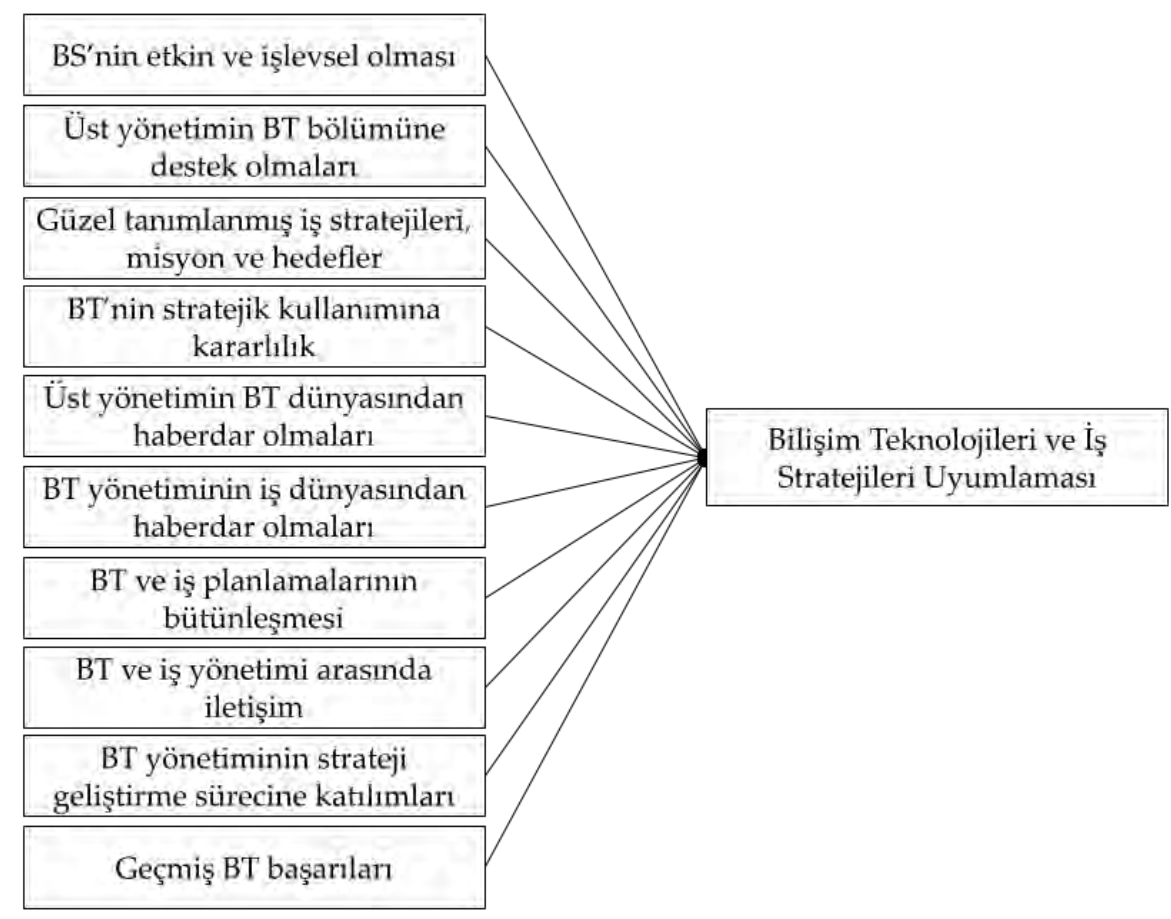

Şekil 1 Araştırma Modeli 


\subsection{Evren ve Örneklem}

Araştırmanın evreni Ankara'da faaliyet gösteren firmalar olarak belirlenmiştir. Örneklem belirlenirken kolayda örneklem yöntemi uygulanmıştır. Ankara Ticaret Odası'nda (ATO) kayıtlı kuruluş sermayelerine göre en büyük 1000 firmanın yöneticilerinin mail adreslerine internet üzerinden ulaşılmaya çalışılmıştır. Bu yolla elde edilen 840 adet mail adresine online anket linki gönderilmiştir. Nisan 2016-Temmuz 2016 tarihleri arasında gönderilen anket mailleri için 175 yönetici dönüş yapmıştır; bu da yanıt oranı olarak yaklaşık \%20’ye tekabul etmektedir. Bunlardan 9 tanesi tutarsızlık ve eksik bilgi olması nedeniyle elendikten sonra 166 cevap üzerinde çalışmanın analizleri yapılmıştır.

Örneklem büyüklügünün analizler için yeterliliği iki ayrı yöntemle doğrulanmıştır. Öncelikle ilgili alanyazındaki bazı çalışmalar örneklemin soru/madde sayısına oranını inceleyerek, örneklem büyüklüğünün madde sayısının en az beş veya on katı olması gerektiğini ifade etmişlerdir (Büyüköztürk, Kılıç Çakmak, Erkan Akgün, Karadeniz, ve Demirel, 2017; Tavşancıl, 2014). Bu çalışmada anket soruları 10 maddeden oluştuğu için 50 veya 100 üzeri örneklem büyüklüğü yeterli bulunacaktır, dolayısıyla 166 cevap adedi analizler için yeterli bulunmaktadır. İkinci olarak anket cevap sayısının yeterliği için Kaise-Meyer-Olkin(KMO) örneklem yeterliliği testi yapıldı. KMO değerleri örneklemin yeterliliğini ve değişkenlerin karşılıklı ilişkilerinin boyutunu ifade etmektedir (Suh, Hillegersberg, Choi, ve Chung, 2012). Akademik çevrelerce 0.5 ve üzeri KMO değerleri örneklemin güvenilirliği açısından yeterli görülmektedir (Field, 2013). KMO değeri bu çalışmada 0.74 olarak bulunarak gerekli kriteri sağladığı görülmüştür.

\subsection{Veri Toplama Aracı}

Anket üç kısımdan oluşmaktadır. Birinci kısımda demografik bilgiler, ikinci kısım bilişim-iş uyumunu ölçmek için sorular, üçüncü kısımda ise faktörlerin uyuma katkısını oyladıkları ve yine aynı faktör için firmalarının algılanan başarılarını belirttikleri kısım yer almaktadır.

Bilişim-iş uyumunun ölçümünde Cragg ve diğ. (2002) ve Chen (2010)'in kullandıkları ölçek kullanılmıştır. Ölçek sekiz farklı iş stratejisi için önce bu stratejilerin firma için önemini/geçerliliğini ölçümleyip daha sonra da aynı strateji için firmanın bilişim sisteminin o stratejiye katkısını beşlik Likert ölçeği ile ölçülerek bu değerlerin tüm stratejiler için ortalamasını alarak elde edilmektedir. Bu sayede BT'nin firma stratejilerine ne kadar katkı sağladığı, firma stratejilerinin gerçekleştirilmesinde BT'nin ne kadar etkin rol oynadığı ölçülmektedir.

\subsection{Verilerin Analizi}

$\mathrm{Bu}$ çalışma sonuçlarının güvenirliği açısından katılımcıların firmanın stratejilerini paylaşan ve firmanın bütüncül resmini okuyabilen yöneticiler olması, diğer bir ifade ile üst düzey yönetim kadrosundan olması gerekmekteydi. Firma için gerekli kıstaslarda ise firmanın yeterli pazar ve BT tecrübesi olması açısından yeni kurulan bir firma olmaması; stratejik yönetime ve kurumsal yapıya sahip olacak kadar hem çalışan hem de yıllık satış rakamları yönünden büyük olması gerekmekteydi. Katılımcı profilleri incelendiğinde çalışma için gerekli olan kriterlerin sağlandığı görülmektedir. Demografik bilgiler Tablo 4 te detaylı olarak verilmektedir. 
Tablo 4 Katılımcılar ve firmaları ile ilgili demografik bilgiler

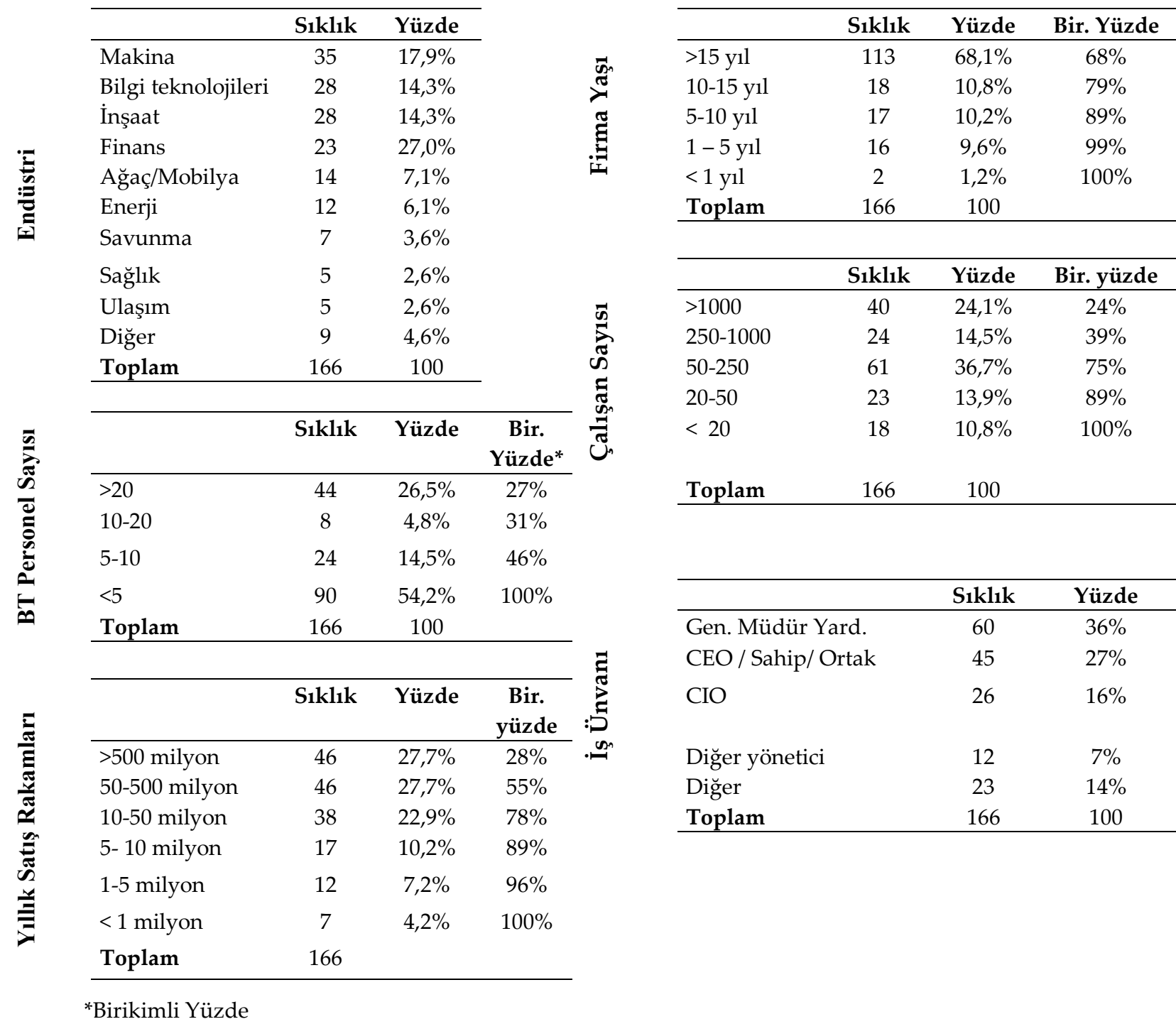

\section{Bulgular}

Bu bölümde yapılan analizler ve sonuçları yer almaktadır. İlk kısımda firmaların BT uyum skoru analizleri, ikinci bölümde yöneticilerin örgütsel faktörlerin BT uyumuna etkisi için verdikleri yantların analizleri, son bölümde ise örgütsel faktörlerin BT uyum skorları ile korelasyon analizlerine yer verilmektedir.

\section{BT-Isş Uyum Skorları}

BT-İş uyumu bu çalışmada Chen (2010) ve Cragg vd. (2002) çalışmaları doğrultusunda firma stratejilerinin bilişim teknolojileri tarafından ne kadar desteklendiği, ilgili stratejilerin uygulanmasında BT'nin ne kadar etkin olarak kullanıldığı üzerinden ölçülmektedir. Bu doğrultuda 8 temel iş stratejisinin öncelikle firma için geçerli olup olmadığı sorulmuş, firmanın ilgili stratejiyi takip etmesi durumunda bilişim sistemlerinin bu stratejiler için katkısı beşlik likert ölçeği ile ölçümlenmiştir. Tüm stratejiler için BT'nin destek değerlerinin ortalaması ise ilgili firmanın BT-İş Uyumlama skorunu belirlemiştir.

Uyum skorları ölçümlerimiz üzerinden elde ettiğimiz veriler bizlere firmaların BT'yi özellikle hangi stratejiler

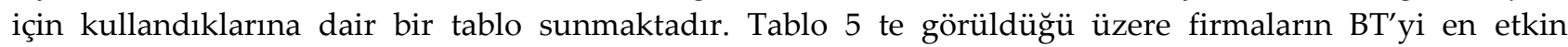
kullandıkları stratejileri operasyon maliyetlerinin düşürülmesi olarak görülmektedir. Onu takiben müşteri hizmetlerinin kalitelileştirilmesi ve üretim süreçlerinin verimleştirilmesi gelmektedir. Yeni pazarlar keşfedilmesi, ürünlerin çeşitlendirilmesi gibi daha yenilikçi ve pazar odaklı stratejilerde BT'nin kullanımı nisbeten düşük kaydedilmiştir. Bu tablodan şöyle bir çıkarım yapılabilir, Türkiye'de bilişim teknolojileri daha 
çok operasyonel verimlilik ve iç süreçler için kullandığı, yenilikçi ve dışa bakan stratejilerde görece geri planda olduğu söylenebilir.

Tablo 5 BT'nin firma stratejilerine katkıları

\begin{tabular}{lcc}
\hline BT ile Desteklenen İş Stratejileri & Ort. & Std. Sap. \\
\hline Operasyon maliyetlerinin düşürülmesi & 4,46 & 0,81 \\
Müşteri hizmetlerinin kalitelileştirilmesi & 4,36 & 1,40 \\
Üretim süreçlerinin verimlileştirilmesi & 4,31 & 1,53 \\
Ürün ve hizmetlerin rakiplerinkinden farklılaştırılması & 4,24 & 0,99 \\
Ürünlerin kalitelerinin artırılması & 3,91 & 1,51 \\
Yeni pazarların keşfedilmesi & 3,73 & 1,34 \\
Ürünlerin çeşitlendirilmesi & 3,72 & 1,38 \\
Yeni ürünleri rakiplerimizden önce piyasaya sürebilmek & 3,64 & 1,38 \\
\hline
\end{tabular}

Genel BT-İş uyumu skorlarına baktığımızda ise örneklemdeki firmalar için genel uyum puanı ortalama 4,06 (Std. Dev: 0,72) olarak bulunmuştur. Bu rakam, Yayla'nın (2008) farklı bir enstrüman kullanmasına rağmen Türkiye'de bulduğu (3,95/5) ile uyumlu olduğu görülmektedir. Genel bir ifade ile Likert ölçeğinde anketteki 4 puan "katılıyorum" a karşılık geldiğinden, yöneticilerin BT"lerinin iş stratejilerini gerçekleştirmede onlara yardımcı olduğuna katıldıkları sonucuna varabiliriz. Şekil 1'de uyum skorlarının sıklık tablosu verilmektedir. Görüldügü üzere ağırlıklı olarak firmaların uyum skorlarının 4 ve üzeri olduğu saptanmıştır.

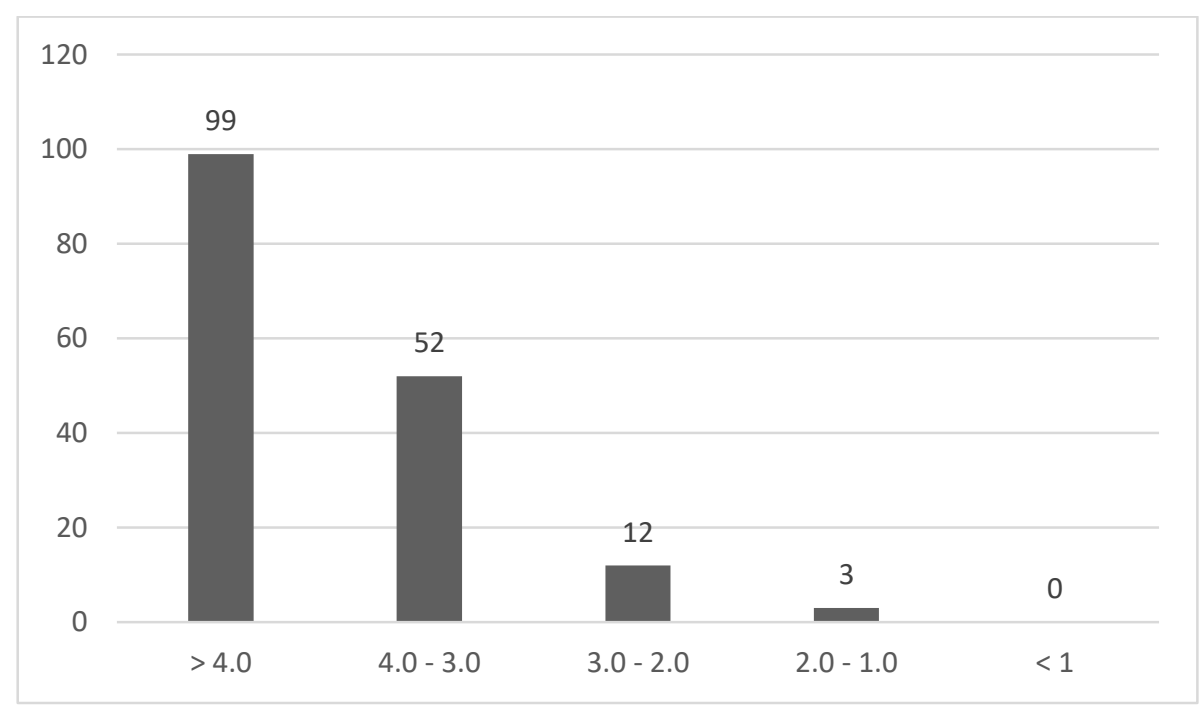

Şekil 2 Firmaların BT-İş Uyumlaması Skorları Sıklık Tablosu

Ayrıca firmaların uyum skorlarını sektörlere göre incelediğimizde taşımacılık, bilişim teknolojileri, finans gibi sektörlerin uyum puanlarının yüksek; makine, savunma ve inşaat gibi üretim ve ağır sanayi bulunduran sektörlerin BT-İş uyumlarının daha düşük olduğu görülmektedir. Ortalamalar arasındaki fark istatistiki olarak anlamlı bulunmuştur ( $\mathrm{p}=0.007$ ). Bu bulgudan hareketle hizmet sektörlerinin üretim sektörlerine göre bilişim sistemlerini daha stratejik kullandıkları çıkarımı yapılabilir.

Tablo 6 Sektörlere göre BT-İş Uyum Skorları

\begin{tabular}{lcc}
\hline Endüstri & Sayı & Ortalama \\
\hline Ulaşım/Taşımacılık & 6 & 4,75 \\
Bilişim Teknolojileri & 28 & 4,66 \\
Finans & 34 & 4,15 \\
Sağlık Hizmetleri & 5 & 4,06 \\
Enerji & 12 & 4,06 \\
Mobilya & 14 & 4,03 \\
Makina & 23 & 3,81 \\
İşaat & 28 & 3,76
\end{tabular}




\begin{tabular}{lccc} 
Savunma & 7 & 3,00 & 3,78 \\
Diğerleri & 9 & 4,05 \\
\hline Toplam & 166 & \\
\hline
\end{tabular}

\section{Örgütsel Faktörlerin BT-İş Uyumuna Etki Analizleri}

Yöneticilerin verdikleri yantlara göre 10 örgütsel faktörün BT-İş uyumuna etkileri ortalama puan ve standart sapma değerleri ile birlikte aşă̆ıdaki tabloda verilmektedir.

Tablo 7 Yöneticilerin oylaması ile elde edilen faktör puanları

\begin{tabular}{lcc}
\hline Örgütsel Faktörler & Ortalama & St. Sapma \\
\hline BS'nin etkin ve işlevsel olması & 4.46 & .556 \\
Üst yönetimin BT bölümüne destek olmaları & 4.42 & .577 \\
Güzel tanımlanmış iş stratejileri, misyon ve hedefler & 4.35 & .699 \\
BT’nin stratejik kullanımına kararlılık & 4.31 & .550 \\
Üst yönetimin BT dünyasından haberdar olmaları & 4.31 & .623 \\
BT yönetiminin iş dünyasından haberdar olmaları & 4.31 & .785 \\
BT ve iş planlamalarının bütünleşmesi & 4.30 & .744 \\
BT ve iş yönetimi arasında iletişim & 4.15 & .710 \\
BT yönetiminin strateji geliştirme sürecine katılımları & 3.92 & .922 \\
Geçmiş BT başarıları & 3.49 & .954 \\
\hline
\end{tabular}

Bu bulgular aynı metotla yapılan iki diğer araştırma ile (Aggarwal, 2010; Teo ve Ang, 1999) karşılaştırıldığında dikkate değer benzerlikler ve farklılıklar görünmektedir. 'BT'nin stratejik kullanımına kararlılık' üç çalışmada da önde gelen faktörler arasında yer almaktadır. Yine 'üst yönetimin BT'ye destek olmaları' da benzer şekilde önemli faktör olarak görünmektedir. Bu çalışmada 'bilişim sistemleri(BS)'nin etkin ve işlevsel olmasının' birinci faktör olmasına rağmen bu faktörün diğer çalışmalarda görece daha düşük çıkması dikkate değerdir. Bu farklılık daha geniş olarak Tartışma bölümünde ele alınmaktadır.

Tablo 4.2 de ise her bir faktör için, firmanın ilgili faktörde algılanan başarısı ile firmanın BT uyum puanlarının Pearson korelasyon değerleri -p değerleri ile birlikte- verilmektedir. 'Üst yönetimin BT dünyasından haberdar olmaları' haricinde tüm korelasyon değerleri istatistiksel olarak anlamlı bulunmuştur.

Listede on faktöre ek olarak firmaların on faktör için algılanan başarılarının toplamı da yer almaktadır. Faktörlerde toplam başarının 0.72 çıkması bir bütün olarak modelin BT uyumu başarısı için güçlü bir gösterge olduğunu göstermektedir. Yine bu değerin diğer tüm faktörlerden büyük olması on faktörün toplam etkisinin tek tek faktörlerin etkilerinden daha fazla olduğunu ortaya koymaktadır.

Tablo 8 Faktörlerin BT Uyumu için Korelasyon Değerleri

\begin{tabular}{lcc}
\hline Örgütsel Faktörler & $\mathrm{r}_{\mathrm{p}}$ & P değeri \\
\hline Faktör başarılarının toplamı & 0,723 &, 000 \\
BT ve iş planlamalarının bütünleşmesi & 0,620 &, 000 \\
BT'nin stratejik kullanımına kararlılık &, 000 \\
Üst yönetimin BT bölümüne destek olmaları & 0,560 &, 000 \\
Geçmiş BT başarıları & 0,429 &, 000 \\
BT yönetiminin iş dünyasından haberdar olmaları & 0,421 &, 000 \\
Güzel tanımlanmış iş stratejileri, misyon ve hedefler & 0,406 &, 017 \\
BT ve iş yönetimi arasında iletişim & 0,382 &, 003 \\
BT yönetiminin strateji geliştirme sürecine katılımları & 0,347 &, 004 \\
BS'nin etkin ve işlevsel olması & 0,334 &, 010 \\
\hline
\end{tabular}


Üst yönetimin BT dünyasından haberdar olmaları

0,123

, 307

İki tablo beraber analiz edildiğinde faktörleri sıralarken reel verilere dayandığı için korelasyon puanlarına öncelik verildi. Yöneticilerin puanlamaları ikincil planda ve destekleyici konumda tutuldu.

Korelasyon katsayıları incelendiğinde $0.40^{\prime} \tan$ büyük 5 faktör güçlü pozitif ilişkiye sahip olduğu görülür: BT ve iş planlamalarının bütünleşmesi, BT'nin stratejik kullanımına kararlılık, Üst yönetimin BT bölümüne destek olmaları/arka çıkmaları, Geçmiş BT başarıları, BT yönetiminin iş dünyasından haberdar olmaları. 'Geçmiş BT başarıları' yöneticilerin puanlamalarında düşük bir puan aldığından elenerek diğer dört faktör için güçlü olumlu etkisi olduğu sonucuna varıldı: BT ve iş planlamalarının bütünleşmesi, BT'nin stratejik kullanımına kararlılık, Üst yönetimin BT bölümüne destek olmaları/arka çıkmaları, BT yönetiminin iş dünyasından haberdar olmaları.

\section{Sonuç ve Tartışma}

Bu çalışmada bazı örgütsel faktörlerin BT-İş uyumuna katkısı iki yolla incelenmeye çalışılmıştır; öncelikle yöneticilerin bu faktörlerin etkisine dair verdikleri puanlar, ikinci olarak da bu faktörlerde firmaların yetkinlikleri ile firmaların BT uyumu skorlarının korelasyon değerleri üzerinden yorumlanması. Araştırma bulguları analiz edildiğinde, yöneticilerin puanlaması ile elde edilen verilerle korelasyon değerleri karşılaştırıldığında dikkate değer farklılıklar bulunmaktadır. Bunlar arasında en göze çarpanı yöneticilerin oylamalarında 5 üzerinden 4.46 ortalama puanla en çok önemli görülen 'BS'nin etkin ve işlevsel olması' faktörünün korelasyon analizlerinde daha düşük katsayılı çıkmasıdır. Ankette opsiyonel olarak sorulan iletişim bilgilerini sağlayan bazı yöneticililerle anket sonrası yapılan telefon görüşmelerinde bu çelişkinin sebepleri sorulmuştur. Bu duruma yöneticilerin BT'den beklentileri arasında ilk ve en birinci olarak işlevsel olması, kusursuz bir şekilde işlemlerin gerçekleşmesi olduğundan bu faktöre öncelik verilmiş olabileceği yönünde fikir birliğine varıldı. Diğer bir ifade ile yöneticilerin bilişim sistemlerinden her şeyden önce sorunsuz çalışmalarını istedikleri, bu yüzden de bu faktöre öncelik vermiş olabilecekleri sonucu çıkarıldı. Bu çıarımı destekleyen diğer bir bulgu da yöneticilerin 'BS'nin etkin ve işlevsel olması' ve 'geçmiş BT başarıları' faktörlerinde kendi firmaları için rapor ettikleri başarı skorlarının düşük olmasıdır.

Analizler neticesinde dört faktörün BT-İ̧s uyumu üzerinde güçlü etkisi olduğu tespit edilmiştir: BT ve iş planlamalarının bütünleşmesi, üst yönetimin BT'ye destek vermeleri/arka çıkmaları ve BT'nin stratejik kullanımındaki kararlılıkları: BT yönetiminin iş dünyasından haberdar olmaları. Tartışma bölümünün bu kısmında bu dört faktörle ilgili detaylı yorumlamalar yapılmış, bulgular literatürdeki diğer çalışmalarla karşılaştırılmıştır.

BT ve iş planlamalarının bütünleşmesi: Bilişim teknolojileri planlaması Lederer ve Mendelow(1989) tarafından: "firma amaçlarına destek olacak bilişim sistemleri projelerinin belirlenmesi ve bu projelerin ayrılan zaman ve bütçe içerisinde geliştirilme süreci" olarak tanımlanmıştır. Şu bir gerçektir ki bu projelerin geliştirilmesi için firmaların ayırabilecekleri zaman ve kaynakları sınırlıdır, bu yüzden bu projelerden yalnızca sınırlı sayıda bir kısmı gerçekleştirilebilecektir. İş ve bilişim planlamalarının bütünleşmesi -entegrasyonu- ise firmanın kendisi için kritik uygulamaları tanımlamasına ve sınırlı olan bütçesinin bu kritik uygulamalara ayrılmasına yardım etmektedir. (Teo ve King, 1996) Bu planlamaların bütünleşmesi sayesinde bilişim sistemleri iş stratejilerine daha eklemlenmiş olacak, bir stratejik araç haline gelecektir. Bu birlikte planlamanın BT uyumuna katkı sağlayacağı teorik/kavramsal çalışmalarda (Henderson ve Venkatraman, 1999) olduğu gibi bazı ampirik çalışmalarda da (Luftman, Kempaiah, ve Nash, 2006; Reich ve Benbasat, 2000; Teo ve Ang, 1999; Teo ve King, 1996) dile getirilmiştir. Örneğin Reich ve Benbasat'ın Leaderer ve Burky (1989) den yaptıkları alıntıda, iş planlamaları sürecine dahil olan BT yöneticilerinin üst yönetimin amaçlarını daha iyi anladıklarını ve iş fırsatları ve problemleri için daha fazla BT çözümleri ile geldiklerini ifade etmektedir.

Üst yönetimin BT'ye destek vermeleri/arka çımaları ve BT'nin stratejik kullanımındaki kararlılıkları: Firmalarda yeni bir uygulamanın geliştirilmesinde ve uygulanmasında yönetimin desteği ve kararlılığı büyük önem arz etmektedir ve bu durum BT projeleri için daha kritik bir seviyede geçerlidir. (Teo ve Ang, 1999) Çünkü BT projeleri zaman ve bütçe gereksinimlerinin büyüklüğü ile öne çıktı̆̆ gibi, uygulanma süreci de firmanın örgütsel yapısına, iş süreçlerine varan büyük değişiklikler getirdiği için üst yönetimin kararlılı̆̆ bu projelerin başarısı için olmazsa olmaz önemi haizdir. Diğer taraftan BT bölümünün firma içerisinde 'arka ofis' 
seviyesinden stratejik paydaş seviyesine kadar değişebilen bir yelpazede konumlanmaları yine yönetimin BT bölümüne karşı tavırları ile belirlenmektedir. Şu açıktır ki, BT'nin stratejik öneminin farkında olan, BT üzerinden yeni iş süreçleri, yeni rekabet stratejileri geliştirebileceklerinin bilincinde olan bir yönetici; BT'yi yalnızca bir gider kalemi, bir hesap ve kayıt tutma aracı olarak gören yöneticiye göre $B T^{\prime}$ yi firma stratejilerine eklemlendirmede daha gayretli olacaktır. (Porter ve Millar, 1985)

BT yönetiminin iş dünyasından haberdar olmaları: Bilişim-şirket uyumu için bu çalışmada etkili bulunan diğer bir faktör olan 'BT yönetiminin iş dünyasından haberdar olmaları' diğer birçok araştırmada da etkin bulunmuştur. Hatta bu çalışmada da olduğu gibi üst yönetimin BT dünyasından haberdar olmalarından daha önemli bulunan bir faktör olmuştur. (Luftman ve diğ., 1999; Teo ve Ang, 1999; Teo ve King, 1996) Bu durum gösteriyor ki artık BT yöneticilerinin BT'nin yalnız teknik boyutu ile alakadar olmaları yeterli gelmemekte, onlardan iş dünyasının temel dinamiklerine hakim olup BT'nin olanak verdiği yeni iş çözümleri sunmaları beklenmektedir. Aksi takdirde onların iş dünyasından habersiz olmaları onların iş meselelerine teknik çözümler getirmelerini engelleyecek, bu ise firmada bilişim sistemleri algısını yalnız teknik-odaklılığa hapsederek, iş-odaklı bir portreden uzak tutacaktır (Teo ve Ang, 1999).

Tartışma bölümünün son kısmında araştırma sonuçlarının uygulayıc1/yöneticiler için neler ifade ettiği belirtilecek, akademik çevreler için çalışmanın kısıtlarından bahsedilip, ileri çalışmalar için önerilerde bulunulacaktır.

\section{1. Çalışmanın yöneticiler için ifade ettikleri:}

Bilişim sistemlerinin, teknolojik gelişmelere paralel olarak firma içerisindeki stratejik konumu arttıkça, yani firmanın temel operasyonlarında, değer zinciri aktivitelerinde, iş süreçlerinde aktif rol oynadıkça bilişim sistemlerinin firma yapısı ve stratejik hedefleriyle uyum içerisinde olması daha bir önem arz etmektedir. Bu uyum aynı zamanda bilişim sistemleri yatırımlarının geri dönüşümlerini arttıracak, firmaya rekabet avantajı sağlayacaktır. Bu çalışmaya katılan yöneticilerden \%94'ünün BT uyumunu çok önemli bulmaları da yine bu uyumun önemini destekler mahiyettedir.

Bilişim-iş uyumunun elde edilmesi ise adımları belirlenmiş bir süreç olmadığından ve ölçülebilir parametreleri bulunmadığından kolay olmadığı ifade edilmektedir. Fakat bu çalışmalarla yöneticilere bir takım niteliklerin firmada mevcut bulunmasının bu uyuma yol vereceğini, zemin hazırlayacağını belirterek; yöneticiler için bu uyumun elde edilme süreci belirsizlikten çıkarılmış, ve onlar için bir yol haritası sunulmuş oluyor. Bu çalışma sonucunda yöneticilere önerilen nitelikler; bilişim ve iş planlamalarının eş güdümlü yapılması, BT bölümüne arka çıkılıp, bir stratejik paydaş olarak görülmesi, bilişim sistemlerinin stratejik kullanımına kararlı olunması ve BT yöneticilerinin iş süreçlerinden, firma faaliyetlerinden, hedef ve amaçlarından haberdar olmasının sağlanması olarak belirlendi.

\section{2. Çalışmanın kısıtları ve gelecek çalışmalar için öneriler}

Bu çalışmada BT-Şirket uyumu için incelenen faktörler yurt dışında yapılmış çalışmalardan alınmış olup Türkiye özelinde geçerli bağlamsal faktörler çalışmanın kapsamı gereği göz önünde bulundurulamamıştır. Bu da Türkiye için çizilecek bir resimde önemli bir ayrıntının gözden kaçırılması riskini barındırmaktadır. Bu eksiklik iş dünyasından yöneticilerle mülakat metodu ile yapılacak bir nitel çalışma ile giderilebilecek, bu nitel çalışma ile çalışmanın bulguları daha somut bir zemine oturtulabilecektir.

$\mathrm{Bu}$ çalışmaya katılımcı firmalar için bir ayrım yapılmadan tüm sektörler dahil edilerek genel bir tablo oluşturulmak istenilmiştir. Bu ise sektörel bazda farklılıkların gözden kaçmasına sebep olabilmektedir. Dolayısıyla daha detaylı sektör özelinde çalışmalar yapıldığında önemli farklılıklar keşfedilebilecek, yöneticilere kendi sektörlerinden daha derinlikli içgörüler sağlanabilecektir.

Son olarak bu çalışmada bilişim-iş uyumu ile firma performansı arasındaki pozitif ilişki literatürdeki ilgili çalışmalara dayandırılarak ayrıca test edilmemiştir. Dolayısıyla bu ilişkiyi Türkiye için inceleyen nicel bir çalışma bu soru işaretini giderecek, bu alana anlamlı bir katkıda bulunmuş olacaktır.

\section{Kaynakça}

Aggarwal, H. (2010). Enablers and Inhibitors of IT Alignment in Indian Petroleum Industry. International Journal of Computational Intelligence Research, 6(1), 171-184. 


\section{S. Altınışık 13/4 (2021) 3194-3205}

Büyüköztürk, Ş., Kılıç Çakmak, E., Erkan Akgün, Ö., Karadeniz, Ş., ve Demirel, F. (2017). Bilimsel araştırma yöntemleri. Bilimsel araştırma yöntemleri. https://doi.org/10.14527/9789944919289

Chan, Y. E. (2002). Why haven't we mastered alignment? The importance of the informal organization structure. MIS Quarterly Executive, 1(2), 97-112.

Chan, Y. E., Huff, S. L., Barclay, D. W., ve Copeland, D. G. (1997). Business strategic orientation, information systems strategic orientation and strategic alignment. Information Systems Research, 8(2), 125-150.

Chan, Y. E., ve Reich, B. H. (2007). IT alignment: what have we learned? Journal of Information Technology, 22(4), 297-315. https://doi.org/10.1057/palgrave.jit.2000109

Chen, L. (2010). Business-IT alignment maturity of companies in China. Information ve Management, 47(1), 9-16. https://doi.org/10.1016/j.im.2009.09.003

Cragg, P., King, M., ve Hussin, H. (2002). IT alignment and firm performance in small manufacturing firms. The Journal of Strategic Information Systems, 11(2), 109-132. https://doi.org/10.1016/S0963-8687(02)00007-0

Field, A. (2013). Discovering statistics using IBM SPSS statistics. Statistics (Vol. 58).

Henderson, J. C., ve Venkatraman, N. (1999). Strategic alignment : Leveraging information technology for transforming organizations. IBM Systems Journal, 32(1), 472-484.

Leaderer, A., ve Burky, L. (1989). Understanding Top Management's Objectives: A Management Information Systems Concern. Journal of Information Systems, 49-66.

Lederer, A. L., ve Mendelow, A. L. (1989). Coordination of information systems plans with business plans. Journal of Management Information Systems, 6, 5-19.

Luftman, J. N., Kempaiah, R., ve Nash, E. (2006). Key issues for IT executives 2005. MIS Quarterly Executive, 5(2), 8199.

Luftman, J. N., Papp, R., ve Brier, T. (1999). Enablers And Inhibitors of Business-IT Alignment. Communications of the Association for Information Systems, 1(March), 1-33.

Porter, M., ve Millar, V. (1985). How information gives you competitive advantage. Harvard Business Review, $149-174$.

Pressman, R. S. (2009). Software Engineering A Practitioner's Approach 7th Ed - Roger S. Pressman. Software Engineering A Practitioner's Approach 7 th $E d \quad-\quad$ Roger S. Pressman. https://doi.org/10.1017/CBO9781107415324.004

Rathnam, R., Johnsen, J., ve Wen, H. (2004). Alignment of business strategy and IT strategy: a case study of a fortune 50 financial services company. Journal of Computer Information Systems, (33), 1-8.

Reich, B. H., ve Benbasat, I. (1996). Measuring the Linkage Between Business and Information Technoiogy Objectives The Linkage Construct : Definitions and Dimensions. MIS Quarterly, (March), 55-82.

Reich, B. H., ve Benbasat, I. (2000). Factors that influence the social dimension of alignment between business and information technology objectives. MIS Quarterly, 24(1), 81-113.

Suh, H., Hillegersberg, J., Choi, J., ve Chung, S. (2012). Effects of strategic alignment on IS success: the mediation role of IS investment in Korea. Information Technology and Management, 14(1), 7-27. https://doi.org/10.1007/s10799012-0144-7

Tavşancıl, E. (2014). Tutumların ölçülmesi ve SPSS ile veri analizi. Nobel Yayıncılık, Ankara.

Teo, T. S. H., ve Ang, J. S. K. (1999). Critical success factors in the alignment of IS plans with business plans. International Journal of Information Management, 19(2), 173-185. https://doi.org/10.1016/S0268-4012(99)000079

Teo, T. S. H., ve King, W. R. (1996). Assessing the impact of integrating business planning and IS planning. Information ve Management, 30(6), 309-321. https://doi.org/10.1016/S0378-7206(96)01076-2

Teo, T. S. H., ve King, W. R. (1997). Integration between business planning and information systems planning: an evolutionary-contingency perspective. Journal of Management Information Systems, 14(1), 185-214.

Weill, P., ve Olson, M. H. (1989). An assessment of the contingency theory of management information systems. Journal of Management Information Systems, 6(1). https://doi.org/10.1080/07421222.1989.11517849

Yayla, A., ve Hu, Q. (2009). Antecedents and drivers of IT-business strategic alignment: empirical validation of a theoretical model, (June). 